\title{
Regional and communal identity in response to politics, Islamism, and Hindutva in North Malabar
}

\author{
Shayju $\mathbf{C}^{*}$ \\ University of Hyderabad, India
}

This paper aims to address particular dimensions of regional and communal identity, concerning the peculiarities of spatial strategies and cultural locations as well as various inter- and intra-community political interactions. Identities of regions and communities are dynamic and evolving in relation to time and space. This paper is an attempt to address the complexities of the Hindu cultural nationalist Islamist politics. In this paper, the emphasis is on how the contemporary social life and politics of North Malabar appropriate and adopt cultural and political aspects of the past, in the creation of an identity in the present. The focus of this paper is more on latent political engagement and structural components of identity than the directly visible forms of articulations and assertions. Latent aspects of political engagements often associated with structural and cultural elements of regional and local societies directly relate to the ideological and political elements. In North Malabar, ethics of folk art and martial tradition are inseparable from various aspects of the latent political engagement. Elements of courage, heroism, martyrdom, altruism, sacrifice and resistance are integral elements in everyday cultural elements of the region. The daily aspect of political engagement and socialisation reinforce these values in terms of regional and community identity. In North Malabar, the ethics of folk culture, and martial art are not only appropriated in political engagement but also functional as crucial elements in various stages of political socialisation.

Key Words: Hindutva, Islamism, spatial strategy, political engagement, political socialization, latent political engagements, ethics of folk culture and martial art.

Article Info: Received: May 23, 2018; Revised: February 25, 2019; Accepted: April 2, 2019; Online: May 31, 2019.

\footnotetext{
* Correspondence address
}

Address: Hyderabad, Telangana 500046, India

Phone: +918985995547 | Email: shyjuhcu@gmail.com

(C)2019 Human Geographies; The authors

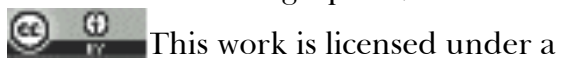

Creative Commons Attribution 4.0 International License. DOI:10.5719/hgeo.2019.131.5 


\section{Introduction}

This article, based on ethnographic research on the latent political engagement in North Malabar, in Kerala state of South India, is focused on latent aspects of political engagements. Latent engagements do not come under the frame of overt articulations, assertions of political behaviour, and direct forms of civic engagements, but formulate the crucial aspects of structural elements of political engagement and involvement with respect to the specific context of the region and society (Ekman \& Amna, 2012). Several aspects of civic and social activities which are not classified as part of political participation, but regarded as 'prepolitical' or 'stand by' are functioning as the latent forms of political involvement or engagement. In latent political engagement, members of voluntary organisations such as youth clubs, football associations, book clubs etc., are more often involved in political activities, than those who are part of political associations (Rogers et al., 1975). This happens in situations, where life politics are more important than conventional methods of participation (Ekman and Amna, 2012). Overt political participation does not involve active civic engagement, but latent political engagements often rely on such activities.

\section{The framework}

This paper aims also to problematize social structure by expanding the concept of structuration by Antony Giddens. 'The structuring qualities of rules can be studied in respect, first of all, of the forming, sustaining, termination, and reforming of encounters. Although a dazzling variety of procedures and tactics are used by agents in the constitution and reconstitution of encounters, probably particularly significant are those involved in the sustaining of ontological security' Giddens (2001 [1984]). Rules are regarded as equivalent to habits or routines. 'However, although routines 'certainly impinge upon numerous aspects of routine practice', routine practice is not as such a rule' (Giddens, 2001 [1984]).

For Steven Loyal, 'Giddens connects rules with practices, so that rules generate - or are the medium of the production and reproduction of - practices. They are not generalisations of what people do but rather the medium, which allows them to act. Rules and practices remain ontologically distinguishable: 'a routine practice is not a rule' (Giddens in Loyal, 2003). For Loyal, what Giddens was arguing was that 'rules in social life are 'techniques or generalizable procedures' understood for the most part of a 'tacit' unformulated basis, which can be applied in the enactment and reproduction of social practices' (Loyal, 2003). Intensive rules refer to procedures that are constantly invoked in the course of day-to-day activities and are exemplified by, for instance, rules relating to language or the procedures used by agents taking turns in conversations. These differ from shallow rules, which, although broader in scope, have a diminished impact on the day-to-day texture of social life. Tacit rules, which refer to the majority of rules implicated within social practices, are only known practically and may be 
contrasted with discursive rules. Such rules imply a prior interpretation of a rule, which therefore may alter the application of them. Formal rules are best exemplified by laws and are generally the most strongly sanctioned types of social rules in modern societies, whilst informal rules refer to those rules, which remain outside the ambit of laws. Although social analysts commonly assume that it is the more general rules, such as codified law, which are the most influential in structuring social activity, it is, in fact, the trivial procedures of daily life which have the most profound and lasting effects.

It is for this reason that Giddens privileges tacit and informal forms of rule over formal and discursive ones (Loyal, 2003). As part of problematizing Giddens' concept of, structuration, in this paper structure is viewed as two parts, the core which is consisted of ethical and moral aspects while the periphery which is about routines and habitus and more interactive with actions and practices are vulnerable to changes in response to the routines and practices. Along with this, the structure can also be analytically divided as more social or cultural parts and the political part. Both the social and political parts of the structure had core and periphery of its own internal structure; the social or cultural structures consists of the ethics and morals as the primary elements of its core, while the political part of the structure comprised of the ideologies as its core. Social or cultural parts and political part are maintaining the equilibrium and reciprocal relations within the structure as well as the reciprocity of the structure with the actions and practices.

\section{Objectives}

This paper aims to demarcate, in the context of North Malabar, the different dimensions of structures and habitus that play a crucial role in the process of structuration. On the one hand, the aspects related to routine and norms of everyday life have an impact on political engagement while the covert aspects of structures and habitus are instrumental in determining the patterns of political engagement, but not always visible in routine or other aspects of everyday life.

\section{Method of study}

This paper includes the findings and observations from the ethnographic study conducted as part of a $\mathrm{PhD}$ research. During an extensive fieldwork that lasted sixteen months, the author participated in different activities of political organisations and neighbourhood activities in the field. The participation included attending daily routines of these organisations, the participation in games and physical training, study classes and discussions as well as attending rallies, demonstrations, and speeches. Group conversations and in-depth interviews were also conducted with members. 


\section{Social history of hinduization and confrontational politics in North Malabar}

This paper on the political engagement of the North Malabar, is based on an ethnographic study in Talassery, Panoor and Nadapuram areas of Kadattanad, a part of Northern Malabar with Southern parts of Kannur district and Northern parts of Kozhikode district in Kerala state, India (Figure 1). Ethics of folk culture and martial art of North Malabar are discussed in this paper, to explain the latent aspects of political engagement. The focus of this paper is on latent aspects of political engagement, rather than explaining the cultural complexity of the region within a frame of cultural politics or culture-politics interface.

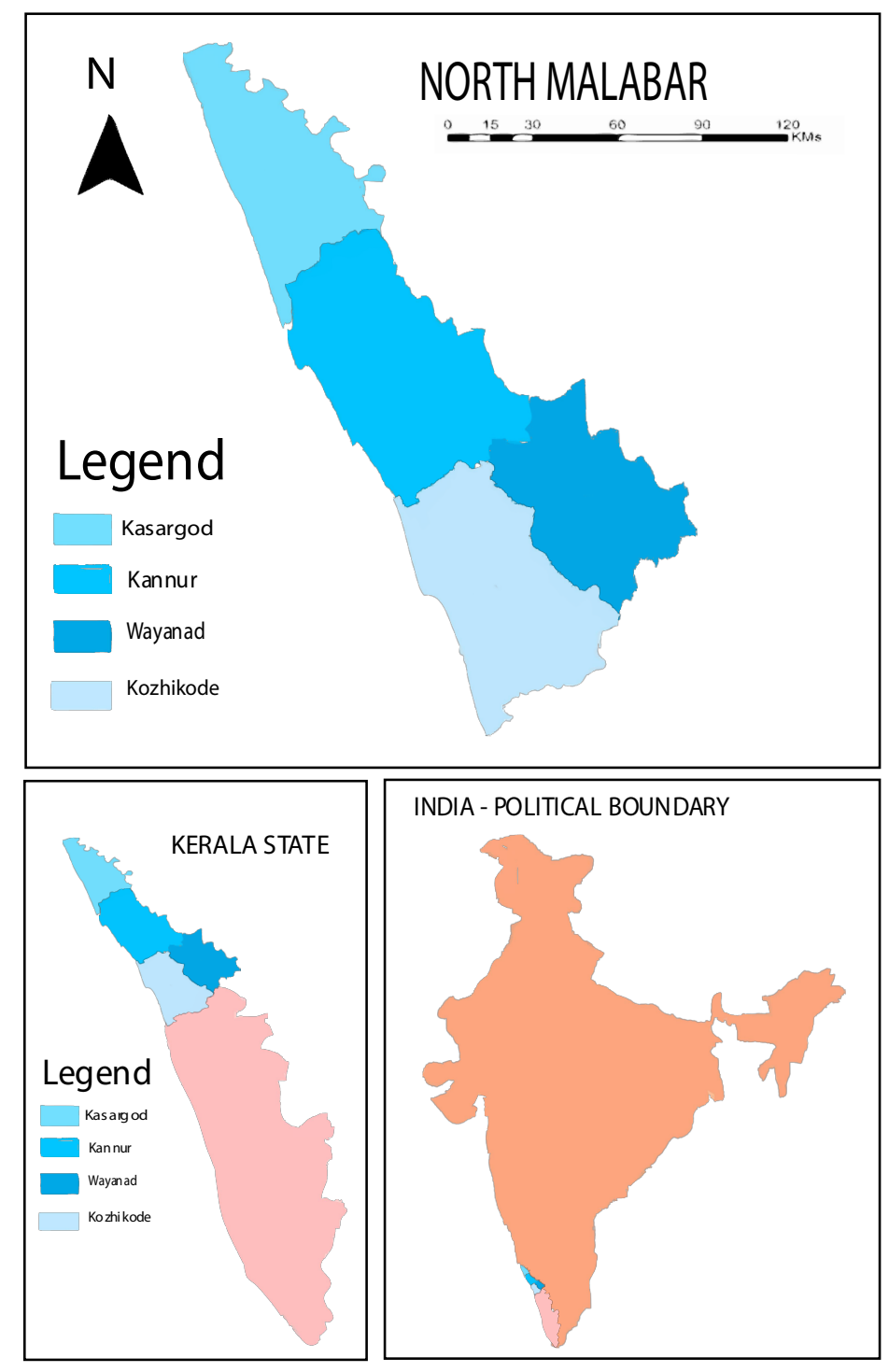

Figure 1. Location and map of North Malabar 
It is impossible to depict the cultural and social history of India, in few paragraphs since the history and cultural traditions in this country were diverse to the point that even now there is no one national culture, rather there are elements associated with nationalism and its political practices. Kerala had a different history of social and cultural structures from the Hindi speaking areas of Northern India. Within Kerala, Northern Malabar has an entirely different history and cultural components unlike the general frame of Brahminical tradition and social hierarchy of varna order (a fourfold hierarchical structure which arranged communities with respect to traditional occupation). According to the national census of 2011 , the population of the country is of $1,210,854,977$ with 623,724,248 males and 586,469,174 females (https://www.census2011.co.in/). India has a population density of 382 persons per $\mathrm{km}^{2}$. While 96.62 cadres $(79.80 \%)$ of the population are Hindus, the Muslims are 17.22 cadres $(14.23 \%)$, and the Christians are 2.78 cadres $(2.30 \%)$. The Sikhs compose $1.72 \%$, the Buddhists are $0.70 \%$, the Jains are $0.37 \%$, people from other remaining religions are $0.66 \%$, while $0.24 \%$ are not stating their religion (https://urlzs.com/fVvhL). In India, there are 121 languages and 270 mother tongues with the speakers' strength of 10,000 and above.

In Kerala, Hinduism constitutes $54.73 \%$ of the population while Muslims are 26.56\% and Christian number 18.38\% (https://urlzs.com/XNN89). In Kerala, Malappuram district in South Malabar is the Muslim majority district with $70.24 \%$ of the population are the Muslims while in all other districts, Hindus are the majority. In other five districts of Malabar including the four in Northern Malabar - Kasargode, Kannur, Wayanad and Calicut/Kozhikode districts - and one in southern Malabar(Palakkad district) - Islam is the second largest religion, while in most of the districts from Travancore and Cochin Christianity prevails. Various tribes in India are also included under different religions. Thus in Kerala, the tribes are considered as Hindus.

The administrative measures of the British during the colonial period, and that of the independent state of India, sanctioned legality for particular patterns of caste and religious identities by the inclusion of several castes and tribes into the Hindu fold. Reform movements influenced the perception of various caste groups and catalysed the process of Hinduization. Among the Tiyyas, the largest non-Muslim community in Malabar, as well as the Ezhava community of Travancore and Cochin (Southern and Middle parts of Kerala), the impacts of Narayana Guru, an Ezhava reformer from Travancore, and the temple entry movements in the 30s propagated orthodox rituals and worshiping of Shiva and Vishnu (Mayer, 1952). For Mayer, as an impact of Narayana Guru, the Tiyyas appropriated more orthodox and 'Vedic' Hinduism in contract to the erstwhile syncretism of the Tiyya and Hindu ceremonies (Mayer, 1952). Prior to the temple entry movements of 1930s, not only the Tiyyas, the Ezhavas and the Dalits (the untouchables in Brahminical Hindu order varna), who were not part of the Brahminical structure called varna order, but also the Nairs, (who were the Shudras, the service castes which come under the lower hierarchy of the fourfold order of varna) were also not allowed to the temples at Guruvayur, Vaikkom etc., 
where Brahminical order was firmly established. The social status of various communities was not static throughout ages. During the period 1766 to 1793 , under Mysorean invasion, the Nairs were treated as slaves, and their women and children were sold in South Malabar (Innes, 1997, 1908). Their caste position was degraded below the Pariahs (Innes, 1997, 1908).

In North Malabar the politics of Indian National Congress evolved as an authority assertion and caste politics of the Nairs built upon connections between Nair taravadus (joint family households), they made use of Congress politics to reassert their influence in several villages (Menon, 1994). Nairs from powerful taravads forcefully shut down the toddy shops of the Tiyyas. Local conflicts predominated over national interest, and the Tiyyas were suspicious of the civil disobedience and temple entry movement led by the Nairs (Menon, 1994). Temple entry movement was seen as an attempt of Hinduization and in a pamphlet released 1936, by the Tiyya Yuvajana Sangham (Tiyya youth organisation) of Kozhikode (Calicut) it was regarded as election propaganda of the Congress (Menon, 1994). C. Krishnan, E. Madhavan, R. Sugunan and other Tiyya leaders propagated the movement of Swatantra Samudayam (independent community) Swathantra Samudaya Darbar and Buddha Mission was conducted at various parts of Kerala (Awaya, 1997).

In some sections of the Tiyya leaders popularising Narayana Guru, there were some Tiyyas who found Hinduization as more depriving and strengthening caste consciousness (Awaya, 1997). Concerning the conversion to Buddhism, on the one hand, the argument was that it was the commitment to Buddhism even after the coming of Brahminism, which lowered the status of the Tiyyas. On the other hand, the resistance to Brahminism was heroic even though it lowered their status under the domination of 'Hinduism' (Awaya, 1997). What prevented the mass conversion of the Tiyyas to Buddhism was the fear of a split in the community against the popularity of Narayana Guru and his stand against conversion. There was nothing to expect in financial terms as in the case of conversion to Christianity.

The attempts from Tiyya elites to build a community of equals against the caste hierarchy of Hinduism was undermined by the differences within the community as well as the decisive role of the Indian National Congress which was more or less an alliance of affluent Nairs (Menon, 1994). The Tiyyas' attempt for the community of equals against the caste difference was countered and its scope was limited by the Nairs led temple entry movement. The community of equals was a challenge to the dominance of Nair taravads and against the interest of the Congress Party. For Menon, the temple entry movement of the Nairs was their personal campaign against the authority of the Brahmins (Menon, 1994). The idea of a community of equals was shifted towards the idea of unity of the Hindus by the Nairs and the Congress. For Awaya, the acceptance among the Tiyyas towards socialism, secularism, and atheism in a later period was related to their affection for Buddhist principles (Menon, 1997).

The rivalry between the Tiyyas and the Mappilas (Malabar Muslims), in colonial North Malabar, cannot be separated from the local political economy. By 1915, 
there were rivalries between Tiyya and Mappila trades, since the modernisation attempts brought more Tiyyas into professions related to trade and commerce (Menon, 1994). The prosperous elites from Tiyya and Mappila communities confronted in Talassery and Kannur towns, in terms of economic competition. The authority of many Nair taravads was challenged by the move of the Tiyyyas to organise a community of equals. The connection between prosperous Mappila merchants and Nair landowners, in pepper trade, was used against the Tiyyas. The conflict between the Tiyyas and the Mappilas could serve the economic and political interests of Mappila merchants and Nair landlords, by dividing the monopoly over trade and land ownership (Menon, 1994). On the other hand, South Malabar had a long history of conflict between the Nairs and the Mappilas. In North Malabar, there was competition between the Tiyyas and the Mappilas, for the ownership for liquor shops. The Indian National Congress (henceforth the Congress), which was a Nair party in Malabar and functioned according to the interests of dominant Nair taravads, led to picketing toddy shops. During the early decades of the twentieth century, the Congress activities and the interests of the Nairs intensified conflicts between the Nairs and the Tiyyas, in the interior, as well as between the Tiyyas and Mappilas, in the coasts (Menon, 1994).

The rivalry between the Tiyyas and the Mappilas dates back to the pre-colonial period. According to the field narratives from Nadapuram, the Tiyyas were a great community in Nadapuram, Kuttiyadi and nearby areas, but colonial administrators wanted to limit the influence of the Tiyyas in Kadattanadu, where they had a rich tradition of martial art. The British, not only banned the practice of kalarippayattu, but also implemented policies in favour of the Mappilas, unlike the colonial situation of South Malabar, where the Mappilas were oppressed in retaliation to the rebellions.

According to the filed data, obtained from the conversations with elderly people, several Mappilas bought land from the Kadattanattu Raja, during the 40s, but the Tiyyas were discriminated, in during the acquisition process. This adversely affected the land relations, since the Tiyya tenants had to work under the newly rich Mappilas, who were asserting their privileges. The Tiyya tenants under the Mappila landowners were subjected to severe exploitation and oppression, while the Tiyya tenants under the Tiyya landowners, were in a better position. The number of Nair, and Nambiar landowners in Nadapuram and nearby areas was lower, but the Tiyya tenants under their land, were in a better position, compared to the Tiyya tenants under the Mappila landholders. The Mappila tenants were also subjected to exploitation, but they did not face the severe atrocities and oppression as the Tiyya tenants faced.

Kurooli Chekkon was a historical figure in Nadapuram, who was shot by the colonial police, for rebelling against the colonial authorities and Kadattanatt Raja (the local king/chieftain of Kadattanadu) as well as Mappila landowners. For the Mappilas, Kurooli Chekkon was a bandit, but for the Tiyyas, he was an admirable figure, who punished the oppressive Mappila landowners. Chekkon was helpful to the poor Mappilas as he was to the Tiyyas. The role of a non-Tiyya Tahasildar (tax officer), to absolve Chekkon at several occasions and the retaliation of some 
police officers towards those who gave information about Chekkon are mentioned in the local narratives. Chekkon was assisted by a tribal youth named Kunkar and a Muslim. He used to plunder the exploitative Mappila landowners and distribute money and goods among the poor Tiyyas and the tribes. Kurooli Chekkon was admired and worshipped as a teyyam (Holy Spirit) till a few years ago, in Vanimel Panchayat of Nadapuram.

\section{Everyday life and political engagement in North Malabar}

In North Malabar, everyday social life includes various civic engagements and political participation through reading rooms, activities of neighbourhood associations, community service and charity, micro financing, sports and cultural activism, etc. In North Malabar, especially in the strongholds of the Communist Party of India (Marxist), the CPIM, in every branch (unit), there are several reading rooms and libraries, under the supervision of local party members and sympathisers. For the Rashtriya Swayamsevak Sangh (the RSS), a Hindutva cultural nationalist organisation, sports, and cultural activities are integral aspects of every shakhas (basic units of the RSS). Kinship-like bonds, fraternal affinity among the cadres, and culpability towards a confrontation between the two organisations are peculiar features in the politics of North Malabar (Chaturvedi, 2012, 2011). The creation of a pantheon of martyrs, appropriation of the folk art form teyyam, as part of political socialisation, and the construction of a political culture to mark a condensation of the history of violence, revolution, and martyrdom are unique aspects of North Malabar (Menon, 2016). While the reading rooms, libraries as well as the daily shakha activities are integral elements to maintaining a habitus in the structuration process in relation to the routine, the belief systems and practices such as the annual commemoration and rituals have a deep role in the structures, other than the aspects of everyday life.

It can be observed in north Malabar, that the elements of confrontational politics rooted in the cultural structure, through the rituals and practices of folk art teyyam, martial art kalarippayattu etc., and associated with the values of sacrifice, martyrdom, heroism, and other virtues, essential for the particular dimensions of political confrontations and political engagement in North Malabar. Resistance and mobilisation are internalized through various forms of folk culture, ethics and practices rather than everyday activities and routines.

For the activists of the CPIM, the RSS, the Muslim League (Indian Union Muslim League) the PFI (Popular Front of India), depending on police, judiciary, and other mechanisms of the local disputes is against the ethics of the locality (the field) as well as a sign of cowardice. For Ganeshan (name changed), a local committee member of the CPIM from Panoor, the RSS conducts murders and attacks on the CPIM cadres and supporters under the supervision of outside pracharaks (missionary like activists). These pracharaks are transferred immediately after a successful operation against the CPIM. This gives the RSS impunity from the police and the law, thus compels the CPIM to retaliate in counteraction. 
According to the cultural logic of Kadattanadu (a part of North Malabar), the support and sacrifice for a great cause, even if it is the resistance against cultural nationalism, to safeguard secularism, cannot be extended if the organization is incapable of keeping the promise of protecting one's comrades. According to this logic, if the enemy is not retaliated, it would give confidence to the latter for further murders and violence, which will be difficult to stop when the enemy became stronger.

\section{Latent political engagement in the cultural structure of North Malabar}

The dominant trend in the study of social engagements and aspects of mobilisation, in the last decade, was to measure activities in terms of formal state institutions, forms of protests and resistance against the state. There is an emerging need to address the aspects of cultural mobilisation and networks of local practices, especially in situations where political engagements are not actions that respond to state institutions (Hart, 1996). For Schiller (1997), the term cultural politics refers to the processes through which relations of power are asserted, accepted, contested or subverted, by ideas, values, symbols, and daily practices. For Jordan and Weedon, culture is used to legitimise the social relations of inequality as well as to contribute to the struggles to transform them (Schiller, 1997).

Cultural politics and structuring is part of everyday social life and various aspects of engagements. The politics of cultural mobilisation have multidimensional elements: of popular culture; of resistance, organised and institutional cultures, etc. The cultural dimension is important in the study of collective movements. Religious traditions or similar structures can provide cultural content, and influence cultural processes by embodying cultural characteristics to strategies of social movements (Hart, 1996). Along with this, the culture making process, also carried out by people with a strong commitment to pre-existing traditions, since they do not just use the traditions opportunistically for the movement objectives, but are more concerned about the traditions and values outside the movement. The scope of inventing new cultures beyond the traditions and values should not be ignored.

For Jordan and Weedon, cultural politics engages in the legitimation of social relations as well as their transformation (Alvarez et al., 1998). Cultural politics determine the meanings of social practices and concerned with subjectivity and identity. Popular actors mobilise collectives on the grounds of very different sets of meanings and stakes, where the collective identities and strategies are inevitably bound by culture. The emphasis on latent aspects of cultural structure, in this paper, is not to explain specific meaning and context of folk performance and martial art, but to examine the significance of their ethics and morals, in everyday life and political engagement in North Malabar. 
Teyyam, the folk dance of North Malabar, which is considered as a form of resistance, use performances to glorify the acts of heroism, sacrifice, and pride, as well as the commemoration of ancestors and local gods. According to a popular saying in North Malabar, 'a Tiyya meets his soul in teyyam'. Teyyam is often conducted in the shrines of the Tiyya community and performed by the Dalits (Menon, 1994). Several aspects of teyyam and martial art tradition are used in performative and contentious politics in North Malabar.

The significant role of commemoration and admiration of the martyrs and their heroic acts is an inevitable part of social life among the Tiyyas and lower castes of the Northern Malabar. In North Malabar, those who became victims of 'upper caste' brutalities, and killed by the landowners are deified to the status of teyyam. Their commemoration as teyyams occurs in annual rituals at the local shrines (Chandran TV, 2005). Many men and women, who rebelled against the Brahminical morality, and the hierarchical order of the caste system, were deified to teyyams after their death. The act of elevating one, to the status of teyyam can satisfy various functions at a time. For the Tiyyas and lower castes, their anger and protest are diverted to the commemoration of teyyam and for the Nair and Nambiar landowners, the fear of possible agitation and the act of revenge from the 'lower castes' or the landless tenants, is limited and diluted by the practice of annual commemoration or teyyattam. At the same time, the use of teyyam as an instrument of domination and appropriation also happened through the ages (Chandran TV, 2005). Several teyyams were incorporated into the Hindu pantheon; Hindu deities were also presented in the form of teyyam. As Russel Ferguson observed, dominant discourses have the tendency never to speak in its own name, but build their authority through absence (Schiller, 1997). For him, the dominant culture is simply assumed to be all-encompassing norms, and thus ensures the basis of its power.

Many martyrs who died in the encounters with the police and feudal authorities were also admired and commemorated for their heroic act and martyrdom. Some of the martyrs were also elevated to the status of teyyam (Menon, 1994, 1992). Many of the teyyam performers were also drawn towards radical political movements, and there are references in the police records to communist dances (Menon, 1997, 1994). Snow et al. (2004), highlighted contextual factors, dimensions, and processes to analyse various kinds of social movements. For Koopmans (2004), the transformative mechanisms of mobilisation, waves of contention, etc., shifts between conflicting and accommodating interactions, radical alterations in the balance of power between groups, and profound realignments of patterns of a coalition as well as the opposition among actors.

One can see several ethics and morals structuring of the forms and patterns of confrontational politics and political engagements in North Malabar, which have more impact than the routines and norms directly visible in the process of structuration. In the social and political field of North Malabar, martyrs are admired as the heroic personalities, who sacrificed their 'life and lifeblood' for the cause of the people and community (Menon, 2016). There were teyyam performances, in the commemoration of martyrs, who were killed in police 
actions. There were several reading rooms and libraries also built in their name. Abdu-Chattukkutty library in Talassery is one among such libraries. For the CPIM cadres and supporters, rakthasakhis (martyrs) are those who fought with the class enemies, and fascist forces to safeguard the life and security of humanity. Martyrs' resolutions and offering red flowers to martyrs' column are a necessary function in conferences apart from the annual commemoration of martyrdom, in the respective date for each rakthasakshi. The word rakthasakshi means the one who testifies history with his or her blood.

While the CPIM cadres and supporters connect martyrdom to the culmination of the specific act, performed by a venturesome comrade, as part of ideological and historical obligations, the RSS and affiliated organizations, the Sangh Parivar (the RSS and related organizations are known as the Sangh Parivar, the family of the Sangh, i.e. the RSS), consider their martyrs as those sacrificed for the cause of the nation, and for its culture (samskaram) and mother nation. The balidanis (martyrs) are treated at par with the heroic warriors in the myths and figures like Shivaji, who, according to the Sangh Parivar, fought against the Muslim rulers in India. The Sangh Parivar conducts balidanjyothi to commemorate the balidanis, offer flowers and recite verses from Gita. For the swayamsevaks of the RSS, the ethics of heroism and selflessness is a devotion to the Sangh (the RSS). One needs to act selfless and volunteer for the Sangh and society. The responsibility and neoKshatriya identity of a swayamsevak is explained as swayameva mrugentrata; 'a lion becomes the king in the wild, not appointed by anyone but by initiating itself.

To attract the youth from the RSS, the CPIM in Kannur district, recently started conducting performative processions and related programs, on the occasion of Shrikrishna Jayati (birthday of Hindu God Krishna). In 2013, several activists and supporting families of the RSS, in Ambadimukku, and other places in Kannur district, switched to the CPIM. These migrations are less important in the study of latent political engagement, since the structure of the social organisation, does not reflect in such incidents. The social organisation of the CPIM and the RSS, is more embedded in the networks and activities of social life. For example, a party village of the CPIM, is a network of cultural and social activities, through reading rooms, libraries, arts and sports clubs, micro-financing etc., which connects the members of a village, in financial and social networks. For the RSS, the sanghagramams (ideal villages following Hindutva notions and cultural practices) are organised, for families and members to socialise, according to the ideals of Hindurashtra. In the Gita gramam (village modelled from the principle of Hindu holy text Gita) Punnad, near Thalasseri, Gita classes are conducted for the members of the neighbourhood. Separate courses are scheduled for each age groups, and at least one Gita class occurs in a day. On Sundays and holidays, all members from the Gita gramam assemble for Gita saptaham (a weekly program of Gita recital) in which, a lecture summarising the lessons of the past week is given, as well as the details of the programs of the coming in the next week. 


\section{The spirit of Teyyam and the ethics of the Chekavars during the contemporary period}

There are two important cultural elements, in determining the political behaviour of the Tiyyas, especially in confrontational politics - the folk element of the teyyam. This evokes the culture and tradition of resistance and the martial tradition of kalarippayattu, which evokes the nobility of the Chekavars (Guild protectors and professional warriors of the medieval period trained in the traditional martial art kalarippayattu). Both aspects are integrated with heroism and sacrifice with a distinction. While the teyyam invokes the ferocious aggressiveness of sacrifice, the invocation to the Chekavars appeals for a fierce fight to win and meet the goals.

The Nair landowners showed contempt and indifference towards the practice of teyyam. During the colonial period, the Congress nationalists looked down at the teyyam, seeing it as irrational acts against the interest of national development, while certain trends of reformation viewed it as instrumental in reproducing caste system, while the left movement explored the possibility of using it as a measure of resistance against the colonial and feudal domination (Menon, 2016, 1994).

The ordinary supporters of the CPIM are more prone to the appeal of the teyyam metaphor that exhibit sacrifice and heroism in mass agitation, confrontation against the police, etc. At the same time, the trained 'fighters' and cadres are often placed with the aura of a Chekavar. The virtues of the teyyam and the Chekavar metaphors exhibited in political participation, are based on the role of confrontation in politics, and subjected to the process of internalization, in response to the operation of political socialization.

Political engagements and mobilization in North Malabar cannot be separated from the tradition of the teyyam. In several myths, a Tiyya is a central hero, where the Dalits, the tribes and the Mappilas also part of rebellious activities against the exploiting landlords (Zahira, 2014). While the teyyam is a metaphor of resistance of a subaltern class, the Chekavars were the heroes from the noble class. While the teyyam metaphor is the recognition of the heroic or sacrificial elements of the spirit after death, the Chekavar metaphor is the personification and the charisma of their will to fight and win. Many of the Chekavars became teyyams after their death but performing the role of the Chekavar in social and political engagement demands different sorts of adventures and abilities than playing the role of teyyam, in mass mobilization. The teyyam metaphor is instrumental for primary political socialization politics. The recognition on par with the Chekavars indicates an advanced level of preparedness. Thus, the subaltern metaphor of resistance and noble ethics of heroism, combined with the ethnic attributes of the Tiyyas, are displayed by the demands and situations of confrontational politics.

The spirit of teyyam is general, universal, inclusive, and distributed across the communities. The ethics of Chekavars are specific, exclusive and specialized, through the standards of a different order; the nobility of the Chekavars in the medieval period, along with the vanguard role of the fighters in the present day political mobilization. In a similar fashion, the rights and duties of a Tandan, the 
Tiyya village headman in the locality of a Tara, an administrative unit in the medieval social organization (Awaya, 1997; Thurston \& Rangachari, 1909), is shifted to the local head of the organization (the CPIM or the RSS), in the contemporary period. The vanguard ethics of the proletarian organization evoked by the CPIM, and the neo-Kshatriya roles in the Hindutva politics used by the Sangh Parivar, are more related to the images of the Chekavars than the cult of teyyam.

\section{Structure of cultural politics in Malabar and the ethnicity of the Tiyyas}

In the case of the Tiyyas, the sense and identity of ethnicity is not something directly articulated for the mobilisation of a community organisation or the purpose of electoral politics. The ethnicity of the Tiyyas is often evoked for confrontational politics but hardly asserted as a communal identity. Without directly invoking the identity of the community, memories of agrarian struggles and rebellion against the landlords are evoked at the situation of confrontations, to prepare the masses for action.

The reference to the tradition and culture of the land is directly related to the agrarian struggles and caste oppression, but the indirect reference is towards the culture of resistance, preserved through the rituals and practice of teyyam worship. At the same time, the admiration for the fighters and charismatic leaders is on par with the role of the Chekavars.

The impact of Chekavar ethics can be compared with a description of a cult personality, which plays a crucial role in the organisation and socialisation of local mobilisation of the CPIM and the RSS in North Malabar. There are several charismatic figures in various localities of North Malabar, who exhibit exceptional heroism and adventurism for the protection of political organisation. Maman Vasu was one among them. Maman Vasu was a 'fighter' for the CPIM, in Panoor. He was the protector of several party villages. He participated in 'operations' to attack the CPIM activists from the RSS. Knowing that Maman was facing a threat from the RSS, the CPIM arranged and prepared cadres to protect him. Each day, he was shifted from one place to another, and his location was not even disclosed to the family members. The RSS consistently prepared for thirteen years to kill him on $12^{\text {th }}$ December 1995. On the other side, the RSS had similar figures like Panyanur Chandran and KT Jayakrishnan.

A detailed description on the political violence in Talassery and Nadpuram can give light to the intensity of the political rivalry between various organisations, but it is not sufficient to analyse the aspects of latent political engagement, as well as the structure of folk elements and martial ethics. The elements of latent political engagement, are often seen in the covert articulations, rather than overt assertions and performances.

In Nadapuram, political engagement and communal identities are interconnected and complicated. Yasser Arafath (2016), mentions the role of Tiyya and Mappila abhyasis (martial art experts), in the communal and political 
rivalries between the Tiyyas and Mappilas. According to the common understanding, the Mappilas were converted from the Nairs and inherited kalari institutions. In reality, according to the practitioners of kalarippayattu, the kalari institutions, in Kadattanadu are not just the places for physical exercise or combat training, but the centres, where the holistic approach of ritualistic traditions followed along with the routine practice of kalarippayattu. The Mappila kalaris are entirely different from such a tradition. The Mappilas entered into kalari traditions during Mysorean invasion, and many of the Mooppans, who recruited Mappila youth to Mysorean army were Tiyyas converts (Menon, 1999).

According to the data from the ethnography conducted in various parts of Talassery, Nadapuram and Panoor, the physical training of the RSS is based on niyuddha, a martial arts form from the state of Maharashtra, where the RSS was formed in 1925. The CPIM, in North Malabar, largely depends on karnatic, the Tulu (southern parts of Karnataka state) style combat system. Nadapauram is part of Kadattanad, where the kalarippayattu has a prominent role among the Tiyyas, but kalarippayattu as a system, is neither used for fighter training nor to settle personal or political conflicts in the present day unless it was in the medieval time of professional warriors the Chekavars. Appropriation of particular techniques from martial arts in combat, is different from internalising the ethics of martial art. According to the practitioners of kalarippayattu, the internalisation of Chekavar ethics is not cultivated through the ritualistic practices and routine of kalarippayattu. Since the ethics of kalarippayattu and kalari institutions are selfmastery and need the cultivation of discipline, kalari institutions associated with the CPIM are not used to train the fighters. The Popular Front of India (the PFI), which emerged as result of several experiments in Nadapuram, trains Muslim youths in combat fight and aggressive campaigning. The PFI, on one hand, attempts to intensify the communal polarisation in Nadapuram, by evoking panIslamic sentiments. On the other hand, the PFI accuses the Muslim league, of being an effeminate and inefficient body to lead aggressive campaigns. Chasing and killing stray dogs, after provoking a fight with a cadre armed with vadivaal (sword stick), is a popular training method of the PFI. Unleashing communal violence and terrifying the locals, with physical or verbal acts, after a confrontation with the opposing organization are regular methods of the PFI.

\section{Masculine and communal identities in confrontational politics}

Caroline Osella \& Filippo Osella (2006) classify various categories of masculine representations in terms of gulf migration. The immature, unmarried male migrant often comes under the gulfan (one who migrated to the gulf countries) identity, the Selfish, or individualistic anti-social man as kallan (fraud), and the generous good guy, innocent to the point of self-destruction, as pavam (innocent). Osella and Osella conducted their fieldwork on gulfan masculinity, in Valiyagramam in Alappuzha, in Travancore (2006; 2000a; 2000b). In Nadapuram, the neo-rich gulfan Mappilas often come under the category of 
kallan, by asserting dominance over poor Mappilas and the Tiyyas as well. According to the field data, when the kallan assertions of a gulfan Mappila, turns against a Tiyya, it often resulted in reactions, and as a consequence, the Mappilas tempt to interpret the reactions as an act of Islamophobia. The communal interpretation and power of the gulf money are very much influential in Nadapuram, to the extent that the confrontation between Tiyya and Mappila men, can transform the identity of a kallan masculinity to pavam masculinity. The popularity of Islamist discourses in Nadapuram, makes it an experimental site. The formation of National Democratic Front was a result of such experiments. Being confident that their identity would not be revealed, some of the Tiyya and Mappila men in middle age disclosed the mystery of the NDF and its connection with the Muslim League. In 1993, at the wake of the ban on Students Islamic Movement of India (the SIMI), the NDF, which was initially known as the Nadapuram Defence Force, in Nadapuram and nearby areas, was formed with the money and influence of gulfan migrants, to mobilize the anti-Tiyya sentiments, in favor of an Islamist agenda. The place where the NDF originated was Tottilpalam, in Nadapuram. Most of the founders were activists of the SIMI or Balasarani, the children's wing of SIMI, which was also active in Nadapuram. To organise the Mappila youth, and liberate them from the 'effeminate' Muslim Leauge, the NDF organised murders and communal violence. A Tiyya youth, Binu was killed in 2001. An allegation of rape was fabricated to justify the killing. The modesty of Muslim women and right over a Muslim female body was the central aspect of the public campaign. To evoke the Muslim sentiments, all such campaigns and rumours in Nadapuram, propagated by the NDF and the Muslim league, at the time of any confrontation contain a Tiyya man on one hand and a Mappila woman on the other. These narratives often present friendship or affairs between the Tiyya men and the Mappila woman as illicit, and the matters of right over the body of Mappila women. In 2006, the NDF, Manitha Neethi Pasarai of Tamil Nadu, and Karnataka Forum for Dignity merged to form the Popular Front of India (Kanchana, 2012).

The emergence of the NDF was a response from few rich Mappilas to overcome the diminishing legitimacy of Mappila landowners and the Muslim League. During the 70s and 80s, the dominance of Mappila landowners was in a better state, though there were resistance and reactions from the Tiyyas. According to Velayudhan (name changed), a Tiyya and a retired schoolteacher from Nadapuram, in the 70s and 80s, there was a band of thugs, known as 'Loonar Set', to protect the interest of the Mappila landowners, and initiate atrocities against the Tiyyas. The 'Loonar Set' was notorious in criminal activities. Poor Mappilas also became their victims along with the Tiyyas. Nambodankandi Hameed, a poor Mappila was killed by Mappila landowner in response to the Hameed's relation with his daughter. The killing of Madompoyil Ibrahim, a member of the 'Loonar set', in retaliation to the act of harassing school girls, in the early years of 80s, was one among the major reactions against 'Loonar Set'. The formation of the NDF (National Democratic Front which later merged in the PFI), was an attempt to reclaim the dominance of the rich Mappilas, most of them are from traditional 
landowning Mappila taravads, who shifted their economic activities, in investments and gulf based business partnerships. The claim of a Mappila aristocracy, as the converts of upper castes, and the idea of the dilemma of the Tiyyas, between Nair and Mappila aristocracies are the systematically established legitimacy claims, which fulfilled the formation of the NDF, and its expansion to the present day PFI. In Nadapuram, systematic efforts of the Muslim League and the PFI, is a success in establishing a widespread perception that the Mappilas of Nadapuram were superior and converted from the Nairs. In reality, the Mappilas of Nadapuram were converted from various sections including the Tiyyas, Paniyas (a tribal community) and polluting castes.

According to field data, the Arangodars, one among the rich traditional Mappila taravads in Vanimal Panchayath, in Nadapuram, were converted from the tribes of the Paniyas. There is a consensus that the few Mappilas at Nadapuram town, were converts of Ravari Nairs. The Ravari Nairs were not an upper caste section among the Nairs. The idea of Nair and Mappila aristocracy being popularized in Nadapuram, is a constructed belief, to legitimise the landowning Mappila taravads' superiority claims. Propagation of this idea is in accordance with the Pan-Islamic narrations and discourses emerging in Malabar. Above all, the attempt to portray the Tiyya-Mappila rivalry as a Hindu-Muslim antagonism serves the interests of the ideology of the Hindutva and the Islamism as well. The imposition of a monolithic subaltern identity over the Tiyyas, reclaiming an aristocracy to assert a masculine identity for the Mappilas, etc., fulfils the agenda of redirecting the socio-cultural and political economic aspects of North Malabar to the realm of Islamophobia and Islamism. The establishment of such binaries notions can help the Hindutva and Islamist forces to divide the population into communal lines. The consequences of such politics can hurt more than denying the Tiyyas their identity, since North Malabar was a place for several political experiments significant in the entire political theatre of the nation, with attempts of communal polarization in favour of the Hindutva, the physical and political resistance against it from the left, or as an approach to make use of the anti-Hindutva sentiments in favour of an Islamist agenda.

\section{Conclusion}

Unlike manifest aspects of political mobilisation, latent aspects of political socialisation are more integrated into the structures of social life. The methods of political engagements and socialisation differ, in accordance with the peculiarities of social organisation. Folk elements and martial art forms play a crucial role in the socialisation of political engagements, in North Malabar.

In North Malabar, the politics of Hindutva, anti-fascist mobilisations of the left, and the Islamist experiments are operating in accordance with the peculiarities of the cultural and structural complexities of the region. The ethics of folk performance and martial art evolved through the ages, and are determinant factors in everyday social life, in which, formal political organisations mediate 
their ideologies and politics, by making use of the ethical codes and structural peculiarities of the region. The elements of confrontational politics are rooted in the cultural structure, through the rituals and practices of teyyam folk art, martial art kalarippayattu etc., associated with sacrifice, martyrdom, heroism and other virtues, essential for the particular dimensions of political confrontations and political engagement in North Malabar. Resistance and mobilisation are internalized through various forms of folk culture, ethics and practices rather than everyday practices and routines. On the one hand, the aspects related to routine and norms of everyday life have an impact on political engagement while the covert aspects of structures and habitus are instrumental in determining the patterns of political engagement, but not always visible in the routine or other aspects of everyday life.

The identity of the region and its communities was developed through several events and incidents throughout several historical stages. This identity was well integrated into the dynamics of social and cultural structures and evolved through the patterns of norms and values. While certain aspects of the inner structures of norms, values, ethics, or morality are resilient through time, certain aspects that continuously interact with the everyday life are changed and reformed according to the legal and democratic principles of the present society. It can be observed in North Malabar that the ethics and values integrated to the spirit of cultural structures are hardly changed, but the aspects of structures interact with the everyday life and political system are transformed in accordance with the modern political and legal system. The patterns of confrontational politics are still operating within the traditional patterns of cultural structures and the spirit of folk elements, but the politics of confrontation has been compelled to reformulate a new modus operandi by incorporating the democratic state and the authority of the legal system.

\section{References}

Alvarez S.E., Dagnino E. and Escobar A. (1998), "Introduction: The Cultural and the Political in Latin American Social Movements" in S.E. Alvarez (ed.), Cultures of Politics, Politics of Cultures: Re-visioning Latin American Social movements, Routledge, New York.

Awaya, T. (1997), "Some Aspects of the Tiyyas' 'Caste' Movement with Special Reference to British Malabar", in H. Kotani (ed.), Caste System, Untouchability and the Depressed (Japanese Studies on South Asia No. 1), Manohar. New Delhi.

Chandran TV. (2005), Ritual as Ideology: Text and Context in Teyyam, Indira Gandhi National Centre for the Arts, New Delhi.

Chaturvedi, R. (2011), "Somehow it Happened': Violence, Culpability, and the Hindu Nationalist Community", Cultural Anthropology, vol. 26, no. 3, p. 340-362. Chaturvedi, R. (2012), "North Kerala and Democracy's Violent Demands", Economic and Political Weekly, vol. XLVII, no. 42. 
Ekman, J. and Amna, E. (2012), "Political Participation and Civic Engagement:

Towards a new Typology", Human Affairs, vol. 22, p. 283-300.

Giddens, A. (2001[1984]), The constitution of Society, Polity Press, Cambridge.

Glick Schiller, N. (1997), "Cultural Identities and the Politics of Culture", Identities: Global Studies in Culture and Power, vol. 4, no. 1.

Hart, S. (1996), "The Cultural Dimension of Social Movements: A Theoretical Reassessment and Literature Review", Sociology of Religion, p. 87-100.

Innes, C.A. and Evans F.B. (1997), Malabar Gazetteer, Kerala Gazetteers Department, F.B. Evans (ed.), Thiruvananthapuram, India.

Kanchana, R. (2012), "Kozhikode (Calicut)'s Kuttichira: Exclusivity Maintained Proudly", in L. Gayer and C. Jaffrelot (eds.), Muslims in Indian Cities: Trajectories of Marginalisation, Hurst Publication.

Koopmans, R. (2004), "Protest in time and Space: The Evolution of waves of Contention", in D.A. Snow et al (eds), The Blackwell Companion to Social Movements, Blackwell Publishing.

Loyal, S. (2003), The sociology of Anthony Giddens, Pulto Press.

Mayer, A.C. (1952), Land and Society in Malabar, Greenwood Press, Westport, Connecticut.

Menon, D.M. (1992), "Conjuctural community: communism in Malabar, 19341948", Economic and Political Weekly, vol. 27, no. 51/52, p. 19-26.

Menon, D.M. (1994), Caste, Nationalism and Communism in South India: Malabar, 1900-1948, Cambridge University Press.

Menon, D.M. (1997), "Peasants and Politics in Malabar", Economic and Political Weekly, vol. 32, no. 41.

Menon, D.M. (1999) "Houses by the Sea: State Formation Experiments in Malabar, 1760- 1800", Economic and Political Weekly, vol. 34, no. 29.

Menon, D.M. (2016), "Pre-history of Violence? Revolution and Martyrs in the Making of a Political Tradition in Kerala", South Asia: Journal of South Asian Studies, p. 662-977.

NA, 2011, All India Religion Census Data 2011, viewed 23 April 2015, https://urlzs.com/Cujd4.

Osella, C. and Osella, F. (2000), "Migration Money and Masculinity in Kerala", The Journal of Royal Anthropological Institute, vol. 6, no. 1, p 117-133.

Osella, C. and Osella, F. (2000), Social Mobility in Kerala: Modernity and Identity in Conflict, Pluto Press.

Osella, C. and Osella, F. (2006), Men and Masculinities in South India, Anthem South Asian Studies, Anthem Press.

Rogers, D.L., Bultena, G.L. and Barb K.H. (1975), "Voluntary Association membership and Political participation: an Exploration of the Mobilization Hypothesis", The Sociological Quarterly, vol. 16, no. 3, p. 305- 318.

Snow, D.A., Soule, S.A. and Kriesi, H. (2004), "Mapping the Terrain", in The Blackwell Companion to Social Movements, D.A. Snow, S.A. Soule and H. Kriesi (eds.), Blackwell Publishing.

Thurston, E. and Rangachari, K. (1909), Castes and Tribes of Southern India, vol. VII, Government Press, Madras. 
Yasser, A.P.K. (2016), "The Nadapuram Enigma: A History of Violence and Communalism in North Malabar (1957- 2015)", Economic and Political Weekly, vol. LI. no. 15 .

Zahira, M. (2014), "Folk Performances: Reading the Cultural History of the Thiyya Community in Kerala", Research in Drama Education: The Journal of Applied Theatre and Performance, vol. 19, no. 2, p. 159- 164. 